\title{
NUTRITIONAL STATUS AND ASSOCIATED FACTORS AMONG NOMAD CHILDREN UNDER FIVE YEARS OF AGE IN DISTRICT FAISALABAD.
}

\author{
Mawera Babar', Rukhsana Khan², Aziz Ullah³
}

${ }^{1} \mathrm{MSPH}$ fellow at Health Services Academy Islamabad

${ }^{2}$ Associate Professor: Community medicine Fazaia Medical College Islamabad

${ }^{3}$ Polio Eradication Officer at WHO.

Correspondence: Mawera Babar, E mail: mawerababar@gmail.com

\begin{abstract}
Background: Globally, more than 150 million under five children are malnourished. In Pakistan $43.7 \%$ of under five children were stunted, $15.1 \%$ were wasted and $31.5 \%$ were underweight according to NNS, 2011 . Nomads are the shifted or migrated people, they are the neglected ones therefore have a very poor health status and knowledge about nutrition. The aim of this study was to improve the nutritional status of the under five nomad children in district Faisalabad. The objectives were to assess the nutritional status of nomad children, knowledge of mothers regarding the nutritional status of their children, factors associated with the nutritional status of these children.

Methods: A cross sectional study was conducted in nomad settlements of four Union councils of district Faisalabad. A structured questionnaire was used and anthropometric measurements like height, weight and MUAC of 296 children selected consecutively were calculated. Results were analyzed by using WHO Anthro to identify stunting, wasting and underweight cases whereas SPSS-20 was used for descriptive and inferential statistics.

Results: Results showed that the proportion of malnutrition among under five children was $86 \%$ in which $10.8 \%$ were wasted, $53.4 \%$ were stunted and $58.8 \%$ were underweight. About $76 \%$ of the mothers have no knowledge about their child's nutritional needs. A significant association was found between malnutrition and sociodemographic, child health and maternal health characteristics including knowledge of mothers.

Conclusion: The nutritional status of the nomad children less than five years was unsatisfactory. Therefore efforts should be made to enhance nomad mothers knowledge through CMW's and LHW's and also provide nutritional support to them.
\end{abstract}

Keywords: Nomad children, stunting, wasting, malnutrition, faisalabad, Pakistan.

\section{Introduction}

Malnutrition is defined as the dearth of sufficient nutrition resulting from deficient food, unbalanced nourishment through diet or incomplete digestion of nutrients (1). The term malnutrition commonly denotes to both under nutrition and over nutrition. Malnutrition occurs when the diet is deficient of enough protein and energy contents and is deficient in all foremost macronutrients e.g. carbohydrates, fats and proteins. The other form of malnutrition which occurs when micronutrients are severely lacking in our diet, it can also causes due to the deficiency of absorption of minerals and vitamins which are essential for our healthy growth and development (2). More than 150 million under five children are malnourished around the world, around $54 \%$ of the young child mortality is linked to malnutrition (3). Around 178 million children under five years are stunted and almost 55 million are wasted and majority of these children are from sub Saharan Africa and South Asia (4). Malnutrition is also a major problem in Pakistan. According to NNS, $43.7 \%$ of under five children were stunted, $15.1 \%$ were wasted and $31.5 \%$ were underweight in 2011. The prevalence of micronutrient deficiencies include $61.9 \%$ of anemia, $43.8 \%$ of iron deficiency, $54 \%$ vitamin A deficiency, $39.2 \%$ of zinc deficiency and $40 \%$ of vitamin D deficiency. Micro and Macronutrient deficiencies are lead to low immunity thus the children are prone to many morbidities like diarrhoeal diseases, ARI's and many other. The main causes of these deficiencies are the lack of awareness and imbalance diet (5).

High prevalence of food insecurity and no access to clean water also lead to the development of nutritional deficiencies (6). Many socioeconomic aspects like low educational status, low socioeconomics, poor nutritional knowledge and lack of resources can also lead to the nutritional problems and malnutrition in under-five children (7). Nomadic tribal populations are the most ignorant population of all others with a very poor environmental conditions; they do not have proper health care services e.g. lack of education, no infrastructure, inaccessibility to hospitals or other 
institutions to seek health care services, mistreated by government staff due to lower background status and lack of acceptance and affordability so all these problems contributes in their poor health status (8).

The word "nomad" derived from Greek word "Nomos" means Pasture. According to Simpson Weiner (1989) it connotes a rover wandering pastoral community. Nomads are the people who move about in search of their livelihood and relaxation from place to place along with their homes and belongings. Today, in numerous regions of world including Faisalabad, Pakistan, nomadic populations are faced with crucial challenges to their current existence, future viability, and especially to their cultural identity (9).

The nutritional status is more importantly associated with child morbidity status, maternal characteristics, environmental conditions and socioeconomic and community factors (10).

The stunting and wasting rates are much higher in rural areas as compared to the urban areas due to their poor living conditions, poverty, maternal factors and low literacy rates. (11) Faisalabad has a high population of nomads. Nomads have large family sizes consists of 510 children on an average and their main source of income is labour or sometimes picking of waste, they have very poor living conditions, low education level and immunization status leading to increase morbidity and mortality (12). Nomadic people live like a separate group in the society and support themselves by occupations that require systematic travel. The health status of nomads is very poor also they did not have proper awareness and access to health services as they keep on migrating from one to another place.

The aim of this study was to improve the nutritional status of the under five nomad children in district Faisalabad. The objectives of the study were to assess the nutritional status of under-five Nomad children living in Faisalabad, knowledge of mothers regarding the nutritional status of their under-five children and to identify the factors related to the nutritional status of under-five children in district Faisalabad.

\section{Methodology}

It was a community based observational cross sectional study conducted in the four union councils of district Faisalabad and was completed in three months. The study population consisted of all nomad children less than five years of age and their mothers residing in these union councils of district Faisalabad. All nomad children up to 59 months of age with their mothers agreed to give the written consent and residing in the rural areas of district Faisalabad. Very sick children and those suffering from congenital abnormalities were excluded from the study. Consecutive sampling method was used as the nomads do not live in houses in any locality. Union Councils 193, 195, 196, and 205 were selected purposely because majority of the nomads were residing there and then identify the households with children under five year who meet the inclusion criteria until the sample size was reached. The sample size was calculated by the formula for estimation and the following assumptions were made: Prevalence of malnutrition $\mathrm{P}=45 \%$ with $95 \%$ Confidence interval, $5 \%$ margin of error. The calculated sample size was 269 and after including $10 \%$ non-response rate the total sample size was 296. A structured questionnaire was used for data collection. The questionnaire was translated into Urdu language for the convenience of study participants. Pretesting of the questionnaire was done on $10 \%$ of the study population in the different area but having the similar characteristics. The tool was edited after pretesting. Five lady health works were hired and trained properly as research assistants during data collection. The translated versions of questionnaire were filled in the presence of principal researcher's supervision. Data analysis was done by using SPSS version 20 and $\mathrm{WHO}$ Anthro software.

Anthropometric measurements like Height, Weight and MUAC of the under five nomad children were also calculated to measure the Stunting and Wasting. Descriptive statistics were calculated like frequencies, percentages, summary statistics and inferential statistics like chi square tests used for association. Those children whose weight for height/length z-score were less than -2 but more than or equal to -3 standard deviation from the median for that reference population will be considered as moderately wasted while those whose WFH z-score were less than -3 standard deviation from the median will be considered as severely wasted, those children whose height/length for age zscore were less than -2 but more than or equal to -3 standard deviation from the median for that reference population will be considered as moderately stunted while those whose height/length for age z-score were less than -3 standard deviation from the median of that reference population will be considered as severely stunted. The criteria was that those children who had one z-score less than standard from the two conditions (underweight and stunting) were considered as malnourished and those children who had both z-scores of the chronic malnutrition more than standard were considered as normal. Those mothers who had knowledge scores equal to or less than mean were considered as having insufficient knowledge and those mothers who had knowledge scores more than mean were considered as having sufficient knowledge. Chisquare test was used to measure the association of malnutrition with the study variables. Proposal was approved by Internal Review Board. Written informed consent was obtained from all participants and the confidentiality of information was maintained at every level. No risk or benefit was given to the participants and monetary benefit was not provided.

\section{Results}

Percentage of males to female children was $51 \%$ and $49 \%$ respectively. The socio demographic characteristics of the study have been shown in the 
table-1 the results showed that the majority of the mothers were illiterate 204(68.9\%) and likewise major proportion of the fathers were also illiterate 263(88.9), most of the families had monthly income less than or equal to ten thousand rupees, $246(83.1 \%)$, the results also revealed that their sanitary conditions were also not satisfactory and $159(53.7 \%)$ had poor sanitary conditions

Table-1: Sociodemographic characteristics of the respondents

\begin{tabular}{|c|c|c|c|}
\hline Variable & & Frequency & Percentage \\
\hline \multirow[t]{3}{*}{$\begin{array}{l}\text { Mothers } \\
\text { age }\end{array}$} & $\begin{array}{l}<18 \\
\text { years }\end{array}$ & 23 & 7.8 \\
\hline & $\begin{array}{l}>18-35 \\
\text { years }\end{array}$ & 234 & 79.1 \\
\hline & $\begin{array}{l}>35 \\
\text { years }\end{array}$ & 39 & 13.2 \\
\hline \multirow{2}{*}{$\begin{array}{l}\text { Mothers } \\
\text { education }\end{array}$} & Illiterate & 204 & 68.9 \\
\hline & Literate & 92 & 31.1 \\
\hline \multirow{2}{*}{$\begin{array}{l}\text { Fathers } \\
\text { education }\end{array}$} & Illiterate & 263 & 88.9 \\
\hline & Literate & 33 & 11.1 \\
\hline \multirow{2}{*}{$\begin{array}{l}\text { Monthly } \\
\text { income } \\
\text { in (PKR) }\end{array}$} & $\ldots$ & 246 & 83.1 \\
\hline & $>10,001$ & 50 & 16.9 \\
\hline \multirow{2}{*}{$\begin{array}{l}\text { Sanitary } \\
\text { condition }\end{array}$} & Normal & 137 & 46.3 \\
\hline & Poor & 159 & 53.7 \\
\hline
\end{tabular}

The child health characteristics are described in the figure $-1,33 \%$ of the children had suffered from diarrhea, $13 \%$ suffered from cough/ARI, $10 \%$ suffered from the other diseases e.g. fever etc, and $56 \%$ had suffered from no disease in the last 14 days.

Child Health Characteristics:

\section{Child health problem in last 14 days}

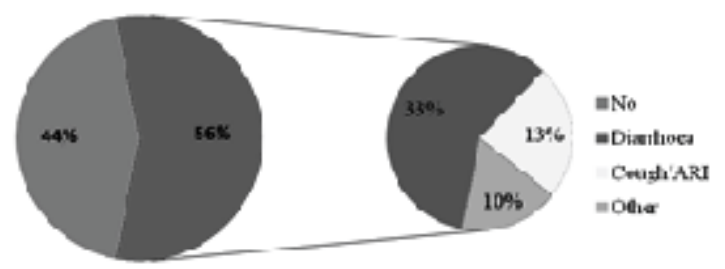

Figure-1: Child Health problems in the last 14 days:
Table-2: Number and percentage of baseline characteristics of respondents

\begin{tabular}{|c|c|c|c|}
\hline \multicolumn{2}{|l|}{ Variables } & Count & \%age \\
\hline \multirow[t]{2}{*}{ Gravidity } & $>4$ & 177 & 59.8 \\
\hline & $\leqslant 4$ & 119 & 40.2 \\
\hline \multirow{3}{*}{$\begin{array}{l}\text { No of } \\
\text { abortions }\end{array}$} & $\leqslant 2$ & 149 & 50.3 \\
\hline & $>2$ & 28 & 9.5 \\
\hline & None & 119 & 40.2 \\
\hline \multirow{3}{*}{$\begin{array}{l}\text { Still } \\
\text { births }\end{array}$} & $\leqslant 2$ & 89 & 30.1 \\
\hline & $>2$ & 80 & 27 \\
\hline & None & 127 & 42.9 \\
\hline \multirow{2}{*}{$\begin{array}{l}\text { ANC by } \\
\text { skilled } \\
\text { person }\end{array}$} & Yes & 28 & 9.5 \\
\hline & No & 268 & 90.5 \\
\hline \multirow{2}{*}{$\begin{array}{l}\text { Mode of } \\
\text { delivery }\end{array}$} & Vaginal & 291 & 98.3 \\
\hline & C-Section & 5 & 1.7 \\
\hline \multirow{2}{*}{$\begin{array}{l}\text { Ever used } \\
\text { any CP } \\
\text { method }\end{array}$} & Yes & 20 & 6.8 \\
\hline & No & 276 & 93.2 \\
\hline \multirow{3}{*}{$\begin{array}{l}\text { CP } \\
\text { method } \\
\text { used }\end{array}$} & Condoms & 4 & 1.4 \\
\hline & Pills & 16 & 5.4 \\
\hline & None & 276 & 93.2 \\
\hline
\end{tabular}

Baseline maternal health indicators of the maternal health are shown in the table 2 , the results revealed that the higher frequency of the women $234(79.1 \%)$ were between 18 to 35 years of age, 39(13.2\%) of the women were above 35 years of age and only $23(7.8 \%)$ were below 18 years of age. The frequency of women with more than four children was $177(59.8 \%)$ while those had less than four children were $119(40.2 \%)$. Majority of the women had not done any antenatal care visits during their pregnancy $268(90.5 \%)$ whereas most of the deliveries were vaginal and done at home 291(98.3\%) 
The frequency of the women that had not used any contraceptive method ever $276(93.2 \%)$ whereas $16(5.4 \%)$ were using condoms and $4(1.4 \%)$ were using pills for contraception.

Anthropometric measurements for Nutritional Status:

Wasting:

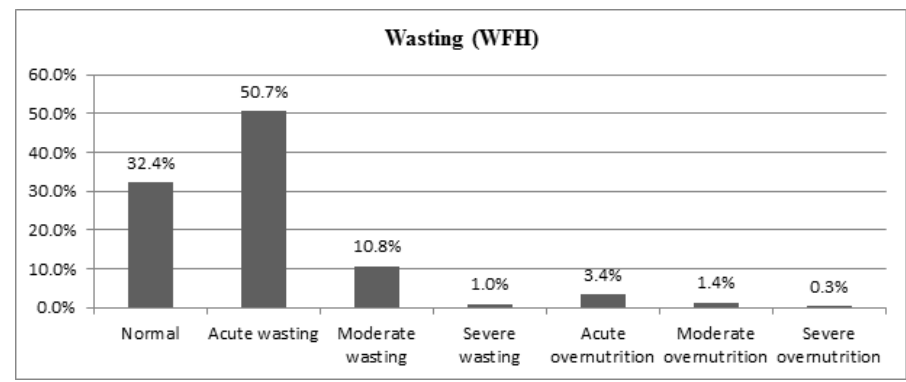

Figure-2: Weight for height Z-score

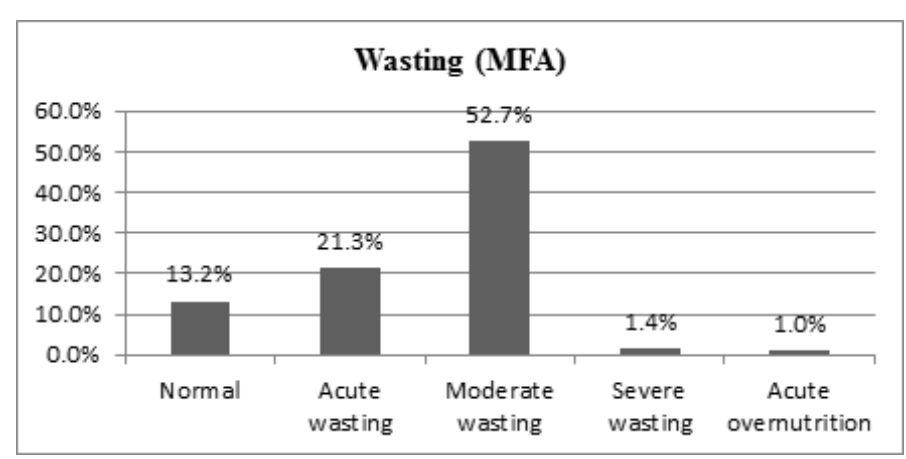

Figure-3: MUAC for age z-score (MFA)

Stunting:

\section{Stunting (HFA)}

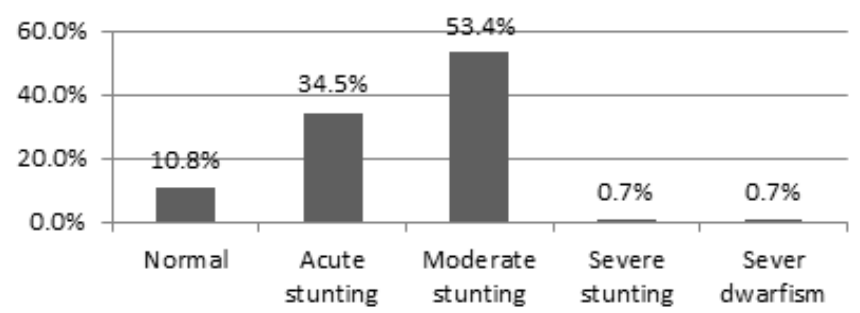

Figure-4: Height for age z-score (HFA)

\section{Underweight:}

Under Weight (WFA)

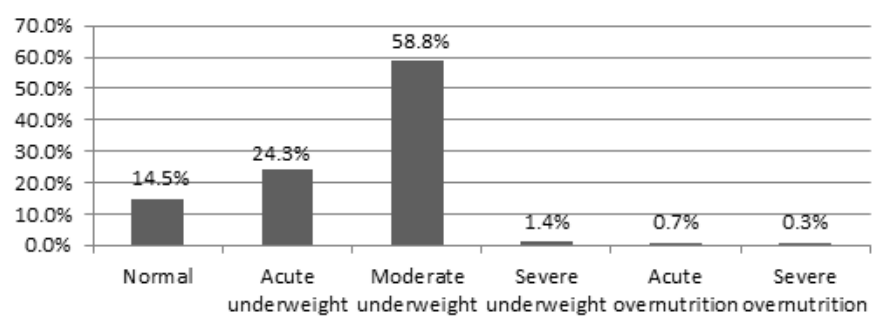

Figure-5: Weight for age z-score (WFA)

The results displayed that $32.4 \%$ of the children were normal, $50.7 \%$ were acutely wasted, $10.8 \%$ were moderately wasted and $1.0 \%$ were severely wasted as displayed in the figure-2, the frequency of moderately stunted were $53.4 \%, 0.7 \%$ were severely stunted, $0.7 \%$ were showed sever dwarfism and $10.8 \%$ of the children were normal as displayed in the figure- 4 . About $58.8 \%$ were moderately underweight, and $1.4 \%$ were severely underweight as displayed in the figure- 5 .

Malnutrition in Nomad Children:

\section{Malnutrition in Nomad children}

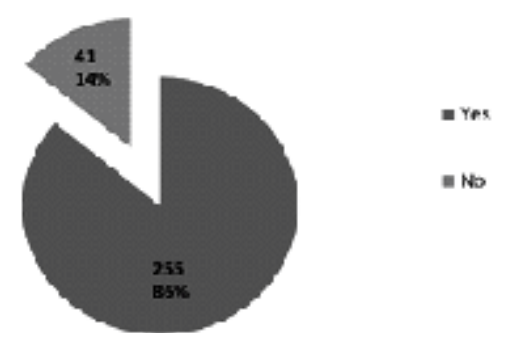

Figure-6: Malnutrition in Nomad Children

The results of the association have been displayed in the table-3.

Table-3: Factors associated with nutritional status in children:

\begin{tabular}{|c|c|c|c|c|}
\hline Variable & & $\begin{array}{l}\text { Normal } \\
\mathrm{n}(\%)\end{array}$ & $\begin{array}{l}\text { Malnourished } \\
\mathrm{n}(\%)\end{array}$ & P-Value \\
\hline \multirow[t]{2}{*}{ Child gender } & Boys & $127(42.9)$ & $17(5.7)$ & 0.321 \\
\hline & Girls & $128(43.2)$ & $24(8.1)$ & \\
\hline \multirow[t]{3}{*}{ Child age } & $\leqslant 6$ months & $29(9.8)$ & $2(0.7)$ & 0.379 \\
\hline & $>6-24$ months & $104(35.1)$ & $16(5.4)$ & \\
\hline & $>24$ months & $122(41.2)$ & $23(7.8)$ & \\
\hline \multirow{2}{*}{$\begin{array}{l}\text { Child sick in } \\
\text { last } 14 \text { days }\end{array}$} & Yes & $155(52.4)$ & $11(3.7)$ & $<0.001^{*}$ \\
\hline & No & $100(33.8)$ & $30(10.1)$ & \\
\hline \multirow[t]{3}{*}{ Mothers age } & $<18$ years & $22(7.4)$ & $1(0.3)$ & 0.15 \\
\hline & $>18-35$ years & $197(66.6)$ & $37(12.5)$ & \\
\hline & $>35$ years & $36(12.2)$ & $3(1)$ & \\
\hline \multirow{2}{*}{$\begin{array}{l}\text { Mothers } \\
\text { education }\end{array}$} & Illiterate & $184(62.2)$ & $20(6.8)$ & $0.003 *$ \\
\hline & Literate & $71(24)$ & $21(7.1)$ & \\
\hline \multirow{2}{*}{$\begin{array}{l}\text { Fathers } \\
\text { education }\end{array}$} & Illiterate & $241(81.4)$ & $22(7.4)$ & $<0.001^{*}$ \\
\hline & Literate & $14(4.7)$ & 19(6.4) & \\
\hline \multirow{2}{*}{$\begin{array}{l}\text { Monthly } \mathrm{HH} \\
\text { income in PKR }\end{array}$} & $\leqslant 10,000$ & $220(74.3)$ & $26(8.8)$ & $<0.001^{*}$ \\
\hline & $>10,001$ & $35(11.8)$ & $15(5.1)$ & \\
\hline \multirow{2}{*}{$\begin{array}{l}\text { Sanitary } \\
\text { condition }\end{array}$} & Normal & $107(36.1)$ & $30(10.1)$ & $<0.001^{*}$ \\
\hline & Poor & $148(50)$ & $11(3.7)$ & \\
\hline \multirow[t]{2}{*}{ Gravidity } & $>4$ & $162(54.7)$ & $15(5.1)$ & $0.001 *$ \\
\hline & $\leqslant 4$ & $93(31.4)$ & $26(8.8)$ & \\
\hline \multirow[t]{3}{*}{ No of abortions } & $\leqslant 2$ & $136(45.9)$ & $13(4.4)$ & $0.026^{*}$ \\
\hline & $>2$ & $24(8.1)$ & $4(1.4)$ & \\
\hline & None & $95(32.1)$ & $24(8.1)$ & \\
\hline \multirow[t]{3}{*}{ Still births } & $\leqslant 2$ & $84(28.4)$ & $5(1.7)$ & $<0.001^{*}$ \\
\hline & $>2$ & $74(25)$ & $6(2)$ & \\
\hline & None & $97(32.8)$ & $30(10.1)$ & \\
\hline \multirow{2}{*}{$\begin{array}{l}\text { ANC by skilled } \\
\text { person }\end{array}$} & Yes & 11(3.7) & $17(5.7)$ & $<0.001^{*}$ \\
\hline & No & $244(82.4)$ & $24(8.1)$ & \\
\hline \multirow{2}{*}{$\begin{array}{l}\text { Mode of } \\
\text { delivery }\end{array}$} & Vaginal & $252(85.1)$ & $39(13.2)$ & 0.088 \\
\hline & C-Section & $3(1)$ & $2(0.7)$ & \\
\hline \multirow{2}{*}{$\begin{array}{l}\text { Ever used any } \\
\text { CP method }\end{array}$} & Yes & $8(2.7)$ & $12(4.1)$ & $<0.001^{*}$ \\
\hline & No & $247(83.4)$ & $29(9.8)$ & \\
\hline
\end{tabular}




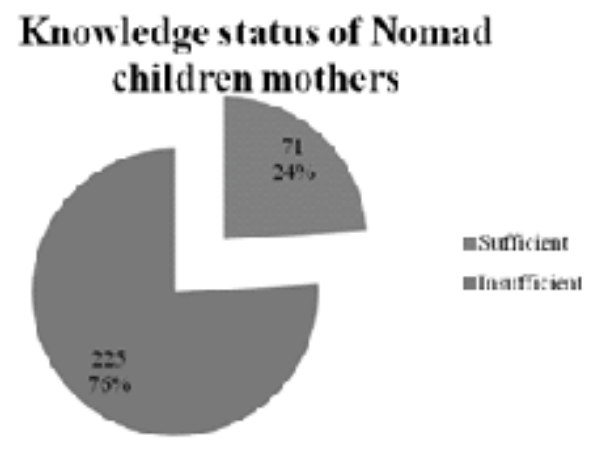

Figure-7: Knowledge status of the mothers of nomad children:

Table-4: Association of knowledge with malnutrition

\begin{tabular}{|c|c|c|c|}
\hline \multirow[t]{2}{*}{ Knowledge } & \multicolumn{2}{|c|}{ Malnutrition } & \multirow[t]{2}{*}{ P-Value } \\
\hline & Yes n(\%) & $\begin{array}{l}\text { No } \\
\mathrm{n}(\%)\end{array}$ & \\
\hline Sufficient & $48(16.2)$ & $23(7.8)$ & $<0.001 *$ \\
\hline Insufficient & $207(69.9)$ & $18(6.1)$ & \\
\hline
\end{tabular}

The results in the figure-7 showed that majority of the mothers had no knowledge about their child's proper diet and nutritional practices $225(76 \%)$ while only $71(24 \%)$ of mothers had knowledge about their child's nutritional practices with the mean score of 4.58 and the standard deviation of 1.29. The association of knowledge have been displayed in the table-4.

\section{Discussion}

The results displayed that the proportion of wasting was $6 \%$ moderate and $3.3 \%$ were severely malnourished. Main factors responsible for the poor nutrition were mainly parental education as mostly both mother and father were illiterate $(76.7 \%$ and $54.0 \%$ respectively). (13)

The results of this study showed that $(35 \%)$ of the children suffered from acute malnutrition according to the weight for height z-score. (14) The study displayed that the malnutrition rates decreased in the test children as WAZ (17.7\%), HAZ (36.5\%), and WHZ (3.2\%) respectively and theses values for the control group were $(5.5 \%, 19.0 \%, 1.5 \%)$ respectively and these differences were statistically significant. (15) This study revealed that the stunting rate of under five children was $(45 \%)$ that showed chronic malnutrition in the study population and wasting rate was $(10.5 \%)$ that showed the acute malnutrition among the study population. (16) The results showed that stunting rate was $48.1 \%$ and wasting rate was $9.7 \%$ among under five children, the study revealed that the socio demographic factors, maternal characteristics and the child characteristics lead to the malnutrition in children. (17)

This study was conducted at the Nomad population of district Faisalabad on under five children. However this study had some limitations like cause and effect relationship could not be established. The results of the study cannot be generalized to the entire population because the sample was not representative. The shortage of time and money was another limitation of the study.

\section{Conclusion}

The nutritional status of the nomad children less than five years was very poor and unsatisfactory. The stunting and wasting rates were high hence the situation is very alarming there. They were having very poor lifestyles with less awareness and no health services available. Another major issue was the lack of family planning and poor hygienic and sanitary conditions prevailing there. A significant association was demonstrated between malnutrition and socio demographic characteristics, maternal health care characteristics, child health characteristics and the knowledge of mothers about the diet of their children. Health Education campaigns and Awareness through LHW's and CMW's regarding nutrition of their children including maternal health. Govt, civil society and NGO's should provide proper jobs to them so they can improve their lifestyle. They should be properly registered by NADRA and should also be provided nutritional support and shelters for living. Additional research in the area of the nutrition of nomad children.

\section{Acknowledgement}

This study was made possible due to the support and great effort of all the concerned persons and the participants, especially the Nutrition Section of UNICEF that funded my research.

\section{References}

1. Collin's English Dictionary. [Internet]. [cited 2015 Nov 15].Available from : www.collins dictionary.com

2. UNICEF. Nutrition Glossary. A resource for communicators. 2012.

3. WHO2002:http://www.who.int/inf-fs/en/ fact119.html,http://www.who. int/nut/ nutrition2.htm, http://www.who.int/nut

4. Bhutta ZA, Salam RA. Global nutrition epidemiology and trends. Annals of Nutrition and Metabolism. 2012;61(Suppl. 1):19-27.

5. Government of Pakistan, Planning and Development Division. National nutritional survey 2011 [Internet]. 2011 [cited 2016 August 4]. Available from: pakresponse.info/ LinkClick.aspx?fileticket=Ao4srwdFVI\%3D\&tab id $=117$

6. Ekpo UF, OmotayoAM, Dipeolu MA. Prevalence of malnutrition among settled pastoral Fulani children in southwest Nigeria. BMC Research Notes. 2008;1(1):7.

7. Maternal and child health baseline survey 
among nomadic pastoralist communities in the Afar region of Ethiopia, The Road Less Travelled Baseline Report - Ethiopia 2012 aroadlesstravelled.net/blog/wpcontent/.../TRLT-Ethiopia-Baseline-ReportFINAL.pdf

8. Abdalla MA, El Tinay AH, Khattab AGH. Socioeconomic aspects influencing food consumption patterns among children under age of five in rural area of Sudan. 2015.

9. Sachdev B. Perspectives on Health, Health Needs and Health Care Services among Select Nomad Tribal Populations of Rajasthan, India. Medical Anthropology.73:81.

10. Lodhi HS, Lodhi FS, Wazir S, Taimoor AR, Jadoon $\mathrm{H}$. Assessment of nutritional status of 1-5 year old children in an urban union council of Abbottabad. Journal of Ayub Medical College, Abbottabad: JAMC. 2009 Dec;22(3):124-7.

11. Arif GM, Nazir S, Satti MN, Farooq S. Child malnutrition in Pakistan: Trends and determinants. Pak Inst Dev Econ. 2012 July.

12. Achakzai P, Khan R. Nutritional Status And Associated Factors Among Children Less Than Five Years Of Age In Tehsil Zarghoon Town, District Quetta, Baluchistan. Journal of Ayub Medical College Abbottabad. 2016 Mar 10;28(1):146-

13. Akhtar S, Akhtar N, Maheen F. A STUDY OF NOMADS IN DISTRICT FAISALABAD. Pak. J. Agri. Sci. 2013 Sep 1;50(3):511-6.

14. Abdalla MA, EI Tinay AH, Khattab AGH. Socioeconomic aspects influencing food consumption patterns among children under age of five in rural area of Sudan. 2015.

15. Frozanfar MK, Yoshida Y, Yamamoto E, Reyer JA, Dalil S, Rahimzad AD, et al. Acute malnutrition among under-five children in Faryab, Afghanistan: prevalence and causes. Nagoya journal of medical science. 2016;78(1):41.

16. Salehi M, Kimiagar SM, Shahbazi M, Mehrabi Y, Kolahi AA. Assessing the impact of nutrition education on growth indices of Iranian nomadic children: an application of a modified beliefs, attitudes, subjective-norms and enabling-factors model. British journal of nutrition. 2004 May 1;91(05):779-87

17. Rayhan MI, Khan MSH. Factors causing malnutrition among under five children in Bangladesh. Pak J Nutr. 2006;5(6):558-62. 